慶應義塾大学学術情報リポジトリ

Keio Associated Repository of Academic resouces

\begin{tabular}{|c|l|}
\hline Title & $\begin{array}{l}\text { Determination of acidic saponins in crude drugs by high-performance liquid chromatography on } \\
\text { octadecylsilyl porous glass }\end{array}$ \\
\hline Sub Title & \\
\hline Author & $\begin{array}{l}\text { 金沢, 秀子(Kanazawa, Hideko) } \\
\text { 永田, 佳子(Nagata, Yoshiko) } \\
\text { 松島, 美—(Matsushima, Yoshikazu) } \\
\text { 友田, 正司(Tomoda, Masashi) } \\
\text { 高井, 信治(Takai, Nobuharu) }\end{array}$ \\
\hline Publisher & 共立薬科大学 \\
\hline Publication year & 1993 \\
\hline Jtitle & $\begin{array}{l}\text { 共立薬科大学研究年報 (The annual report of the Kyoritsu College of } \\
\text { Pharmacy). No.38 (1993. ),p.54-54 }\end{array}$ \\
\hline JaLC DOI & \\
\hline Abstract & \\
\hline Notes & 抄録 \\
\hline Genre & Technical Report \\
\hline URL & https://koara.lib.keio.ac.jp/xoonips/modules/xoonips/detail.php?koara_id=AN00062898-0000003 \\
\hline & $8-0054$ \\
\hline
\end{tabular}

慶應義塾大学学術情報リポジトリ(KOARA)に掲載されているコンテンツの著作権は、それぞれの著作者、学会または出版社/発行者に帰属し、その権利は著作権法によって 保護されています。引用にあたっては、著作権法を遵守してご利用ください。

The copyrights of content available on the KeiO Associated Repository of Academic resources (KOARA) belong to the respective authors, academic societies, or publishers/issuers, and these rights are protected by the Japanese Copyright Act. When quoting the content, please follow the Japanese copyright act. 


\title{
Determination of Acidic Saponins in Crude Drugs by High-Performance Liquid Chromatography on Octadecylsilyl Porous Glass
}

\author{
Hideko Kanazawa, Yoshiko Nagata, Yoshikazu Matsushima, \\ Masashi TOMODA and Nobuharu TAKAI** \\ 金沢秀子，永田佳子，松島美一，友田正司，高井信治**
}

We prepared an octadecylsilyl porous glass (MPG-ODS) and reported that it was a useful packing material for reversed phase high-performance liquid chromatography (HPLC). Saponins of ginseng, the root of Panax ginseng and other crude drugs were determined by HPLC on MPG-ODS.

Neutral dammarane saponins (ginsenosides- $R b_{1}, R b_{2}, R c, R d$ ) and an acidic saponin (ginsenoside-Ro, a glucuronide saponin of oleanolic acid) isolated from ginseng have been extensively studied from the chemical, pharmacognostic and pharmacological view points. Prof. Kitagawa, Osaka University, and his coworkers reported that white ginseng contains a considerable amount of acidic malonate of the dammarane saponins, malonyl-ginsenosides $\mathrm{Rb}_{1}, \mathrm{Rb}_{2}, \mathrm{Rc}$ and $\mathrm{Rd}$. These malonyl-ginsenosides are rather unstable and readily demalonylated by heating. Recently, acidic malonate of saikosaponins, malonyl-saikosaponin a and $d$ were also isolated from bupleurum root. Other well known acidic saponins are those contained in senega. Senega is the roots of Polygala senega and has been used as an expectorant. Acidic saponins of Senega, senegins II, II', III and IV, are the glycosides of pentacyclic triterpens and the sugar moieties contain glucose, fucose, rhamnose, xylose, galactose and so on.

In traditional oriental medicine, several crude drugs are generally prescribed in a single formula. Ginseng is one of the most important crude drugs in the medicine. Bupleurum root is often prescribed with ginseng.

HPLC analysis on octadecylsilyl porous glass was investigated for acidic saponins in ginseng, bupleurum root and senega. The acidic saponins, malonyl-ginsenosides, malonylsaikosaponins and senegins, as well as neutral saponins in the crude drugs were separated rapidly by HPLC on this column with aqueous acetonitrile containing $\mathrm{KH}_{2} \mathrm{PO}_{4}$ as the mobile phase. Simultaneous determinations of the acidic and neutral saponins were successful at room temperature.

* 本報告は J. Chromatogr., 630, 408-414 (1993) に発表

** 東京大学生産技術研究所 